\title{
Decontamination of Wastewaters Containing Organics by Electrochemical Methods
}

\author{
Florica Manea and Aniela Pop
}

Additional information is available at the end of the chapter

http://dx.doi.org/10.5772/53142

\section{Introduction}

The ultimate goal of the sustainable wastewater management is the protection of the environment in a manner commensurate with public health and socio-economic concerns [1]. Industrial effluents containing toxic and refractory organic pollutants cause severe environmental problems and their removal or degradation is required. Industries like petrochemical, chemical, pulp and paper, dyeing and pharmaceutical generate a variety of toxic organic compounds, and among them, phenol derivates have received an increased attention in the last years [2-4]. From phenol derivates, the most toxic compounds are the chlorinated and nitro-substituted phenols, which are used as pesticides and bactericides [3]. In most countries, the maximum allowable concentration of phenol derivates in the effluent streams is required to be less than 1 ppm [5], because these derivates cause several serious health problems: e.g., liver and kidney damage and blood pressure drop, cardiac toxicity including weak pulse, cardiac depression and reduced blood pressure [6]. Hence, phenol derivates must be treated to satisfy the stringent water quality regulations and the demand for recycling of water in the process [2]. The objective of Integrated Pollution Prevention and Control (IPPC) Directive [7] regarding the industrial effluent reuse as raw water into production process represents a challenge for the wastewater treatment technologies. Usually, for the treatment of the industrial effluents containing refractory organics, the conventional wastewater treatment for organics removal or destruction are ineffective to reach the water quality appropriate for its reusing, and new alternative methods are required.

During the last years, the electrochemical processes have been developed as alternative options for the remediation of wastewaters containing organic pollutants, due to the main advantages of the electrochemical methods, e.g., environmental compatibility, versatility, high energy efficiency, amenability of automation and safety, and cost effectiveness. The 
electrochemical technology currently offers promising approaches for the prevention of pollution problems from industrial effluents, acting in principal as „end-of-pipe” technology [8-11].

Electrochemical processes should be regarded as viable alternatives for enhanced conventional wastewater treatment technology. Based on the wastewater type, composition and their further usage, the various electrochemical processes could be applied individually or/and integrated into a variety of technological flows involving physical, chemical and biological methods. Thus, the electrocoagulation process could replace the conventional coagulation method integrated into a technological flow containing or not the electrooxidation process as advanced water treatment method. Also, the electrooxidation process could be applied as advanced oxidation process suitable especial for degradation/mineralization of the recalcitrant organic pollutants. However, there are many important aspects for the optimization of an electrochemical process, starting with the electrochemical process type, continuing with the electrode materials and not the least, the operating variables, like the current density and $\mathrm{pH}$.

\section{Electrochemical process for organics separation}

Electrocogulation represents an important technique for investigation and application of the electrochemical treatment of wastewaters containing organics as alternative for the coagulation process $[8,12,13]$. In general, during the electroflotocoagulation process the coagulant is generated in-situ by "sarcrificial anodes", the most usual being aluminium or iron electrodes. The electrolytic dissolution of aluminium anode lead to the generation of $\mathrm{Al}^{3+}$ and $\mathrm{Al}(\mathrm{OH})^{2+}$ at low $\mathrm{pH}$, which are converted into $\mathrm{Al}(\mathrm{OH})_{3}$ at appropriate $\mathrm{pH}$ values and finally polymerized to $\mathrm{Aln}(\mathrm{OH}) 3 \mathrm{n}$, which acts the same as in the coagulation process. Also, $\mathrm{Fe}(\mathrm{OH}) \mathrm{n}, \mathrm{n}=2,3$ is produced by electrolytic dissolution of iron anodes are dissolved by electrolysis, which can remove the pollutants from wastewaters. The metal hydroxides act as coagulant species, which destabilise and aggregate the suspended particles and precipitates and adsorb dissolved and suspended pollutants (e.g., suspended solids, dissolved organic matter). The metal anode dissolution is accompanied by hydrogen gas evolution at cathodes, the bubbles capturing and floating the suspended solids formed and thus removing pollutants $[14,15]$. The presence of organic and suspended matter activates or inhibits these main electrode processes partially by adsorption on electrode and involvement in surface film formation. Also, the presence of $\mathrm{Cl}^{-}, \mathrm{SO}_{4}{ }^{2-}$ anions influences the aluminium dissolution, with further involvement in the electrocoagulation process [12]. Good process efficiencies have been reported for electrocoagulation applying on wastewaters $[12,14,16,17]$, and also, greater efficiency for the removal of chemical oxygen demand (COD) parameter and suspended solids in comparison with conventional coagulation process [15]. The main advantages of electrocoagulation versus coagulation are simple equipment and easy operation, no chemical added and a smaller amount of precipitate and sludge [8]. 


\section{Electrochemical oxidation of organics}

Electrochemical oxidation represents a very promising way for the treatment of wastewaters containing organic pollutants. Taking into consideration the conventional wastewater treatment flow, the electrooxidation methods exhibit great potential either for replacement of conventional process with electrooxidation one or its integration within the technological flow [18]. Two approaches have been proposed by Comninellis [19] of the electrooxidation process in wastewater treatment:

- so-called electrochemical conversion method, in which the bio-recalcitrant organics are transformed into biodegradable compounds;

- the electrochemical combustion or incineration method, considered as advanced electrooxidation process that allows a complete degradation or mineralization of organic pollutants.

The electrochemical conversion process should be integrated prior to the biological stage of the conventional wastewater treatment to enhance the biodegradability degree and as consequence, the biological treatment performance.

The advanced electrooxidation process is based on the electrochemical generation of hydroxil radicals $(\bullet \mathrm{OH})$, which is a very high powerful oxidant able to mineralize the organic pollutants from water [20].

Two different oxidation mechanisms for the electrochemical oxidation of pollutants have been proposed: direct anodic oxidation, where the pollutants are destroyed at the anode surface, and indirect oxidation where the oxidation process occurred via a mediator that is electrochemically generated. In general, during the electrooxidation of wastewaters, both oxidation mechanisms may coexist with different proportions in direct relation with the electrode material and operation conditions [21].

The key of the electrochemical process performance is given by the electrode material, which should to exhibit several properties, e.g., high physical and chemical stability, resistance to corrosion and formation of passivation layers, high electrical conductivity, catalytic activity and selectivity, low cost/life ratio. Also, a very important aspect for the electrode material assessment is the potential value at which the side reaction of oxygen evolution occurs. High $\mathrm{O}_{2}$ overvoltage electrodes with large potential window are suitable for an effective electrooxidation of organics from wastewater. Carbon-based electrodes represent an attractive electrode material for electrooxidation with respect to the abovediscussed features. A large variety of carbon electrodes suitable for the degradation of organics from aqueous solution have been reported, e.g., glassy carbon [22-24], carbon pastes [25], and boron-doped diamond electrode [26-29].

The performance of new carbon based electrode materials for organics electrooxidation are presented and discussed in this chapter, pointing out: their preparation, the electrochemical characterization of new carbon based composite electrode materials comparative with the new commercial boron doped diamond electrode (BDD) and the conventional glassy carbon (GC) electrode, the assessment of electrochemical activities of each material for the target 
pollutants, i.e., 4-chlorophenol, 4-nitrophenol, 4-aminophenol, 2,4-dichlorophenol and pentachlorophenol by the chronoamperometry and multiple-pulsed amperometry technique application. Also, the results of 4-aminophenol degradation by photocatalytically-assisted electrochemical process using BDD electrodes are presented in this chapter. In addition, the dual role of the electrode material and electrochemical method for both organics degradation and detection is briefly presented.

\section{Experimental procedures}

\subsection{Preparation of carbon composite materials}

Carbon-based composite electrodes presented in this chapter, i.e., expanded graphite-epoxy (EG-Epoxy), carbon-nanofiber expanded graphite-epoxy (CNF-EG-Epoxy), expanded graphite-silver-zeolite-epoxy (AgZEG) and expanded graphite-polystyrene (EG-PS) composite electrodes were obtained by film casting and respective, hot press methods.

\subsubsection{Epoxy matrix}

The composite electrodes, i.e., expanded graphite-epoxy (EG-Epoxy), carbon-nanofiber expanded graphite-epoxy (CNF-EG-Epoxy), expanded graphite-silver-zeolite-epoxy (AgZEG), made using epoxy matrix were obtained from two-component epoxy resin (LY5052, Araldite / 5020 Aradur) mixed with conductive expanded graphite (EG) fillers powder and silver modified zeolite (clinoptilolite) [30-32]. The ratio was chosen to reach 20 weight percent $(\mathrm{w} / \mathrm{w})$ for each component, i.e., expanded graphite (EG), carbon nanofibers (CNF) (PS-447 BOX), silver- zeolite ion-exchanged function of the electrode composition. The mixing was performed in a two roll-mill at room temperature. For the EG-Epoxy and

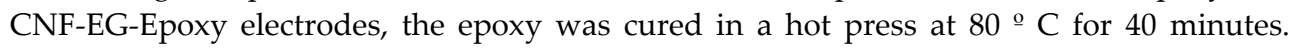
Simultaneously, the material was shaped in a plate of $1 \mathrm{~mm}$ thickness. The plate was slowly cooled down (for about $12 \mathrm{~h}$ ) to the room temperature without removing the applied pressure. The electrodes were made cutting plates of $9 \mathrm{~mm}^{2}$ and put on a glass supports and electrical contacts were made using a silver paint. For AgZEG electrode, the resulting pastes from the two roll-mill procedure were embedded in polyethylene and electrical contacts were made using copper wire, and discs with a surface area of $19.63 \mathrm{~mm}^{2}$ were obtained. Prior to use, the working electrode was gradually cleaned, first polished with abrasive paper and then on a felt-polishing pad by using $0.3 \mu \mathrm{m}$ alumina powder (Metrohm, Switzerland) in distilled water for 5 minutes and rinsing with distilled water.

\subsubsection{Polystyrene matrix}

The expanded graphite-polystyrene (EG-PS) composite electrode was prepared from low viscosity polystyrene pellets (PS N2000, Crystal from Shell) mixed with conductive expanded graphite (EG) filler powder (Conductograph, SGL Carbon). EG was added to a toluene (Fluka) solution of PS N2000 with constant stirring. Ultrasound was used for about $2 \mathrm{~h}$ to mix well the components. The obtained viscous mixture was cast into a film using a 
Teflon mold and the toluene was left to evaporate at room temperature for $48 \mathrm{~h}$, and then in a vacuum oven at $50{ }^{\circ} \mathrm{C}$ for $24 \mathrm{~h}$. The final thickness of the obtained film was about $1 \mathrm{~mm}$ [33]. Plates with a surface area of $9 \mathrm{~mm}^{2}$ were cut from the composition and put on a glass supports and electrical contacts were made using a silver paint. The electrodes were isolated on the sides by epoxy resin.

\subsection{Structural and electrical characterization}

The carbon-based composite electrodes were characterized morphologically by scanning electron microscopy and a homogeneous distribution of carbon filler within the insulating matrix was found [30-32]. The electrical resistance of each electrode was measured by a fourpoint resistance method [34] and the results are gathered in Table 1.

\begin{tabular}{|c|c|}
\hline Electrode & Electrical resistance $\left(\Omega \mathrm{cm}^{-1}\right)$ \\
\hline EG-Epoxy & 5.3 \\
\hline CNF-EG-Epoxy & 11.6 \\
\hline EG-PS & 3.2 \\
\hline
\end{tabular}

Table 1. Electrical resistance of the carbon composite electrodes

\subsection{Electrochemical characterization of the carbon electrodes}

The carbon composite electrodes have been studied in comparison with commercial glassy carbon (GC) and boron-doped diamond (BDD) electrodes provided by Metrohm, Switzerland, and respective, Windsor Scientific Ltd., UK. The electrochemical characterization of the electrodes was carried out by cyclic voltammetry (CV). All measurements were carried out using an Autolab potentiostat/galvanostat PGSTAT 302 (Eco Chemie, The Netherlands) controlled with GPES 4.9 software and a three-electrode cell, with a saturated calomel electrode as reference electrode, a platinum counter electrode and carbon based working electrode.

\subsection{Bulk electrolysis and photocatalytically-assisted electrolysis experiments}

The electrochemical degradation experiments were carried out by batch process using an undivided cell of $1 \mathrm{dm}^{3}$ volume, for different organics concentrations in $0.1 \mathrm{M} \mathrm{Na}_{2} \mathrm{SO}_{4}$ supporting electrolyte. The BDD/Nb electrodes $(100 \mathrm{~mm} \times 50 \mathrm{~mm} \times 1 \mathrm{~mm})$ with $280 \mathrm{~cm}^{3}$ geometric area provided by CONDIAS, Germany were used as anodes, and stainless steel plates $(100 \mathrm{~mm} \times 50 \mathrm{~mm} \times 1 \mathrm{~mm}$ ) were employed as cathodes under vertical arrangement. A regulated DC power supply (HY3003, MASTECH) was used under galvanostatic regime at 5 and $10 \mathrm{~mA} \mathrm{~cm}^{-2}$ current densities.

The photocatalytically-assisted electrolysis experiments were performed under the similar working conditions as the electrolysis experiments in the presence of $1 \mathrm{~g} \mathrm{dm}^{-3} \mathrm{TiO}_{2}-$ supported zeolite catalyst $[35,36]$. The suspension was illuminated with a $6 \mathrm{~W}$ UV lamp 
emitting 254-365 nm wavelengths. The intensity of UV lamp was about $2100 \mu \mathrm{Wcm}^{-2}$, the illumination surface area of $32.15 \mathrm{~cm}^{2}$, and the distance between UV lamp and cell surface was $5 \mathrm{~cm}$.

After each 30 minutes, samples were drawn from the cell and organics degradation was monitored by UV-vis spectroscopy. Also, total organic carbon (TOC) parameter was used to check organics mineralization. UV-vis spectrometric measurements were performed on a Varian 100 Carry using $1 \mathrm{~cm}$ quartz cell, and TOC content of the samples was analyzed at a Shimadzu TOC analyzer. Measurements of $\mathrm{pH}$ were done by an Inolab WTW pH meter.

\subsubsection{Analytical procedures}

The degradation process efficiency $(\eta, \%)$ and electrochemical degradation efficiency (E, $\left.\mathrm{mg} / \mathrm{C} \cdot \mathrm{cm}^{2}\right)$ for organics degradation was determined based on equations (1) and (2) $[37,38]$ :

$$
\begin{gathered}
\eta(\%)=\frac{\left(C_{\text {org }, i}-C_{\text {org }, f}\right)}{C_{\text {org }, i}} \times 100 \\
E=\frac{\left(C_{\text {org }, i}-C_{\text {org }, f}\right)}{C * S} \times V\left(\mathrm{mg} / \mathrm{Ccm}^{2}\right)
\end{gathered}
$$

where $C_{o r g, i}-C_{o r g}, f$ is the change in the organic concentration determined by spectrophotometry during experiments for a charge consumption of $\mathrm{C}$ corresponding to various electrolysis time, $\mathrm{V}$ is the sample volume $\left(700 \mathrm{~cm}^{3}\right)$ and $\mathrm{S}$ is the area of the electrode surface $\left(\mathrm{cm}^{2}\right)$.

The electrochemical efficiency for organics mineralization was determined based on equation (2) modified as (3) taking into consideration the change in TOC measurements during experiments, determining $\left(\mathrm{TOC}_{0}-\mathrm{TOC}\right)$

$$
E_{\mathrm{TOC}}=\frac{\left(\mathrm{TOC}_{0}-\mathrm{TOC}\right)}{C * S} \times V\left(\mathrm{mg} / \mathrm{C} \mathrm{cm}^{2}\right)
$$

The mineralization current efficiency (MCE) for each electrolyzed solution was calculated based on equation (4) [39]:

$$
M C E=\frac{n F V_{s} \Delta(T O C)_{\exp }}{4.32 \times 10^{7} m I t} \times 100(\%)
$$

where $n$ is the number of electrons consumed in the mineralization process of $4-\mathrm{AP}, \mathrm{F}$ is the Faraday constant $\left(=96487 \mathrm{C} \mathrm{mol}^{-1}\right), \mathrm{V}_{\mathrm{s}}$ is the solution volume $\left(\mathrm{dm}^{3}\right), \Delta$ (TOC) exp is the experimental TOC decay $\left(\mathrm{mg} \mathrm{dm}^{-3}\right), 4.32 \times 10^{7}$ is a conversion factor for units homogenization $\left(=3600 \mathrm{~s} \mathrm{~h}^{-1} \times 12000 \mathrm{mg}\right.$ of carbon $\left.\mathrm{mol}^{-1}\right), \mathrm{m}$ is the number of carbon atoms in organic, I is the applied current (A), and $t$ is time (h). The number of electrons consumed is determined based on the overall mineralization reaction of organics to $\mathrm{CO}_{2}$ 
The specific energy consumption, $\mathrm{W}_{\mathrm{sp}}$, was calculated with the relation (5):

$$
\mathrm{W}_{\mathrm{sp}}=\mathrm{C}_{\mathrm{sp}} \times \mathrm{U} \quad\left(\mathrm{kWh} \mathrm{dm}^{-3}\right)
$$

where $C_{\text {sp }}$ represents the specific charge consumption of $C$ corresponding to $1 \mathrm{dm}^{3}$ and $U$ is the cell voltage $(\mathrm{V})$.

\section{Results of organics degradation by electrochemical and photocatalytically-assisted electrochemical oxidation}

\subsection{Electrochemical behaviours of the carbon based electrodes in the presence of organics}

\subsubsection{Cyclic voltammetry studies}

The electrochemical behaviours of the carbon based electrodes in $0.1 \mathrm{M} \mathrm{Na}_{2} \mathrm{SO}_{4}$ supporting electrolyte were studied by cyclic voltammetry $(\mathrm{CV})$ to explore the organics oxidation process on the electrodes in order to clarify the relationship between experimental variables and the electrode response, and also, to determine the potential window and the oxygen evolution reaction potential value. As can be seen in Figure 1, the AgZEG electrode exhibited the oxidative/reductive peak corresponding to redox peaks of the $\mathrm{Ag} / \mathrm{Ag}(\mathrm{I})$ couple. For this electrode, the background current is similar with CNF-EG-Epoxy, and higher than for the EG-Epoxy electrode, also a common aspect for the electrocatalytic electrode type. In the presence of organic pollutant, 4-chlorophenol, chosen as an example of monosubstituted phenol derivates, an anodic oxidation peak appeared at the potential values presented in Table 2, which are prior to the oxygen evolution potential. No evidenced oxidation peak occurred at GC electrode even if a slight current increase was found in the presence of 4chlorophenol, which informed that there is no limiting current characteristics to the transport control. Except BDD electrode that can be classified as high $\mathrm{O}_{2}$ overvoltage electrode (Eo2 about $1.5 \mathrm{~V}$ vs. $\mathrm{Ag} / \mathrm{AgCl}$ ), the others shloud be regarded as low $\mathrm{O}_{2}$ overvoltage electrodes (Eo2 about $1 \mathrm{~V}$ vs. $\mathrm{Ag} / \mathrm{AgCl}$ ) characterized by a high electrochemical activity towards oxygen evolution and low chemical reactivity towards oxidation of organics. Effective oxidation of pollutants at these electrodes may occur at low current densities due to at high current densities, significant decrease of the current efficiency is expected due to the oxygen evolution. In contrast, at high $\mathrm{O}_{2}$ overvoltage anodes, higher current densities may be applied with minimal contribution from the oxygen evolution side reaction.

Except 2, 4-dinitrophenol, which exhibited the oxidation potential of about $1.2 \mathrm{~V}$ vs. $\mathrm{Ag} / \mathrm{AgCl}$, similar results regarding the oxidation peak appearance at the potential value before oxygen evolution were found for other phenolic derivates, i.e., 4-aminophenol, 4nitrophenol, 2,4-dinitrophenol and pentachlorophenol (the results are not shown here). However, for mono- and di-nitro substituted phenol derivates, the cathodic current increased at the potential value of about $-0.4 \mathrm{~V} \mathrm{Ag} / \mathrm{AgCl}$, which was ascribed to the reduction of $-\mathrm{NO}_{2}[40,41]$. In addition, in the cathodic potential range a polymer of aminophenol formed cathodically could occur. The polymer resulted from 2,4-dinitrophenol 
is less stable than the polymer resulting from mono-substituted nitrophenol, and can be further oxidized and mineralized [42].

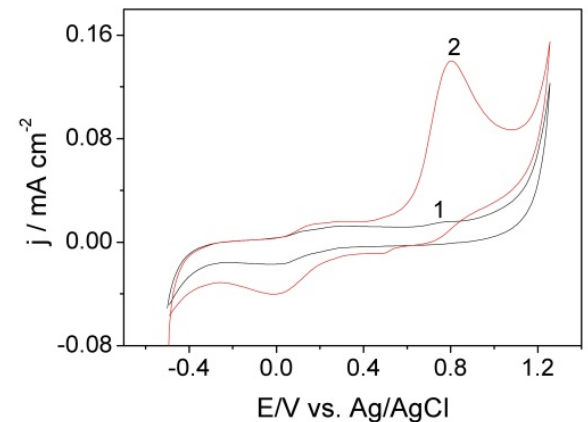

a)

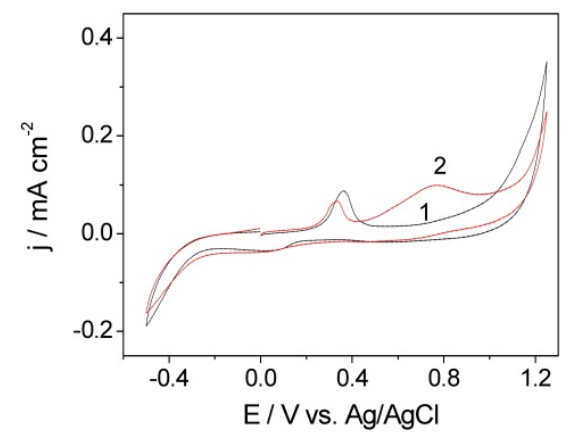

c)

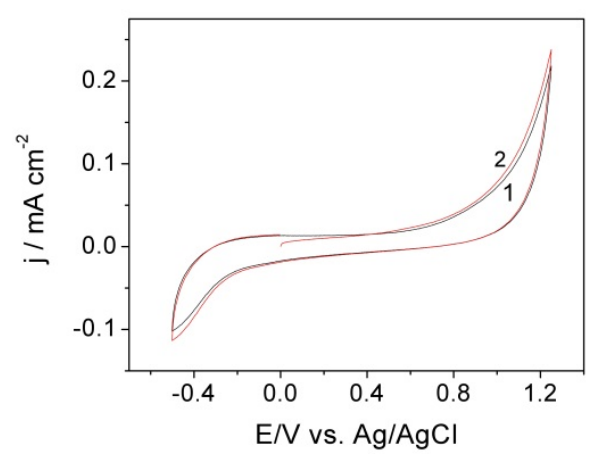

e)

Figure 1. Cyclic voltammograms recorded with a potential scan rate $0.05 \mathrm{Vs}^{-1}$ between 1.25 and $-0.5 \mathrm{~V}$ vs. SCE in a $0.1 \mathrm{M} \mathrm{Na}_{2} \mathrm{SO}_{4}$ supporting electrolyte (curve 1 ) and in the presence of $25 \mathrm{mg} \cdot \mathrm{L}^{-1} 4-\mathrm{CP}$ (curve 2) at a) EG-Epoxy, b) EG-CNF-Epoxy, c) AgZEG. d) EG-PS; e) GC; f) BDD electrode.

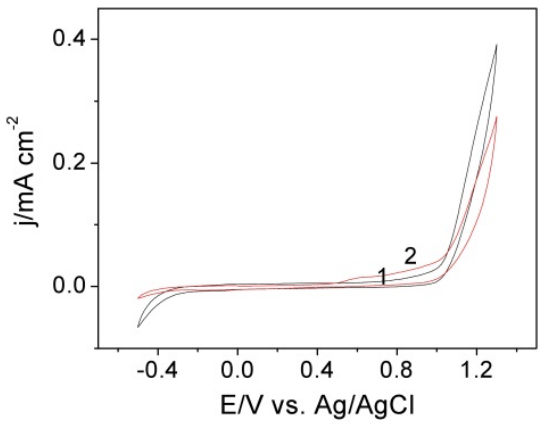

b)

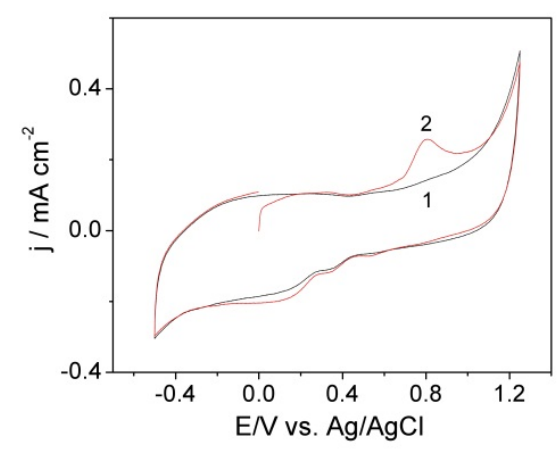

d)

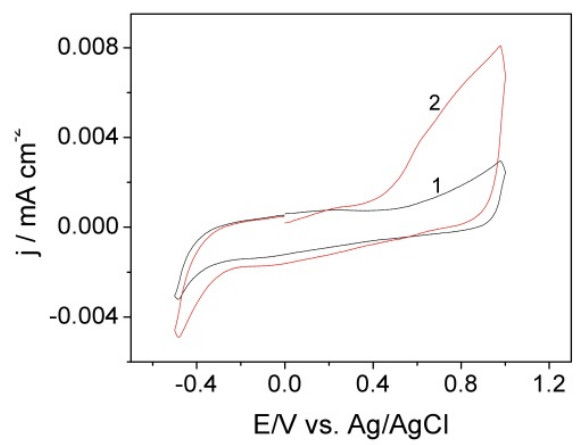

f) 


\begin{tabular}{|c|c|c|c|c|}
\hline $\begin{array}{c}\text { Electrode } \\
\text { material }\end{array}$ & $\begin{array}{c}\text { Scan } \\
\text { number }\end{array}$ & $\Delta \mathrm{j}\left(\mathrm{mA} \cdot \mathrm{cm}^{-2}\right)$ & $\begin{array}{c}\text { Anodic peak current } \\
\text { densities reduction } \\
\text { degree }(\%)\end{array}$ & $\mathrm{E}(\mathrm{V})$ \\
\hline EG-Epoxy & 1 & 0.12323 & - & 0.8 \\
& 2 & 0.07492 & 39.2 & 0.8 \\
CNF-EG-Epoxy & 3 & 0.05743 & 53.4 & 0.8 \\
& 1 & 0.01184 & - & 0.8 \\
AgZEG & 3 & 0 & 100 & 0.8 \\
& 1 & 0 & 100 & 0.8 \\
EG-PS & 2 & 0.04467 & - & 0.8 \\
& 1 & 0.03495 & 37.5 & 0.8 \\
& 2 & 0.24299 & 51.1 & 0.8 \\
BDD & 3 & 0.15065 & 38.00 & 0.8 \\
& 1 & 0.12344 & 49.20 & 0.8 \\
& 2 & $0.720 \cdot 10^{-3}$ & - & 0.6 \\
& 3 & $0.895 \cdot 10^{-3}$ & 64.88 & 0.6 \\
\hline
\end{tabular}

Table 2. Voltammetric parameters for $25 \mathrm{mgL}^{-1} 4$-CP oxidation on carbon based electrodes.

It can be noticed that starting with second CV the peak current decreased by quite $100 \%$ for CNF-EG-Epoxy composite electrode, which is due to the electrode fouling. For other electrodes the peak current decreases by the similar order starting with the second CV. The effect of the scan rate on the anodic peak current of the first CV has been investigated for each carbon-based electrode in $0.1 \mathrm{M} \mathrm{Na}_{2} \mathrm{SO}_{4}$ supporting electrolyte and in the presence of $25 \mathrm{mg} / \mathrm{L} 4-\mathrm{CP}$ (the results are not shown here). The linear proportionality of the anodic peak current with the square root of the scan rate obtained for all tested electrodes indicated process control by mass transport. No intercept of 0 suggested that the adsorption steps and specific surface reaction cannot be neglected. The most strong adsorption effects were noticed for EG-CNF-Epoxy electrode, these results being in concordance with those obtaining by three consecutive scanning using CV. Even the oxidation potential value is almost constant the 4-CP oxidation is not reversible because no corresponding reduction cathodic peak appeared by backward scanning. In general, the electrode fouling owes the complex mechanism of phenols oxidation on carbon based electrode, which involves both the adsorption of reactant/intermediate or final oxidation products and the formation of passive, nonconductive layer of oligomer products of oxidation process on its surface [4346]. Silver ions introduction within the electrode composition in order to act as catalyst is not justified based on $\mathrm{CV}$ results regarding the electrode activity towards $4-\mathrm{CP}$ at various concentration. AgZEG electrode exhibited a slight lower electrochemical activity in comparison with EG-Epoxy electrode (see Figure 2).

For all tested phenolic derivates the similar behaviours of the carbon-based electrodes regarding the presence of the limiting current density (ilim) corresonding to the phenolic derivates oxidation peak were found by cyclic voltammetry. CV results must be considered 
as reference for electrooxidation applying under galvanostatic regime (constant current). Thus, depending on the applied current density (iappl), two different operating regimes have been identified $[43,47]$ i.e., iappl<ilim the electrolysis is under current control with the current efficiency of $100 \%$ and iappl $>\mathrm{ilim}$ the electrolysis is under mass-transport control and the secondary reactions of oxygen evolution are involved with a decreasing of current efficiency. However, the choice of iappl must consider the process or electrochemical efficiency, which is limited by the electrode fouling and also, the electrical charge consumption.

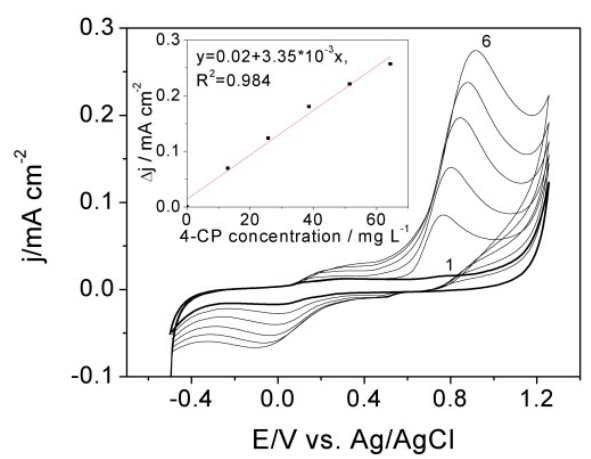

a)

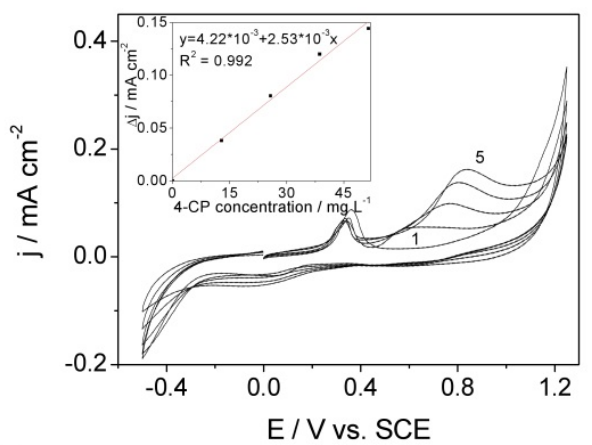

b)

Figure 2. Cyclic voltammograms of a) EG-Epoxy and b) AgZEG in the presence of different 4-CP concentrations: $1-0 \mathrm{mM} ; 2-12.5 \mathrm{mgL}^{-1} ; 3-25 \mathrm{mgL}^{-1} ; 4-37.5 \mathrm{mgL}^{-1} ; 5-50 \mathrm{mgL}^{-1} ; 6-62.5 \mathrm{mgL}^{-1}$ in a) $0.1 \mathrm{M}$ $\mathrm{Na}_{2} \mathrm{SO}_{4}$ supporting electrolyte; potential scan rate $0.05 \mathrm{Vs}^{-1}$. Inset: the calibration plots of the current densities vs. 4-CP concentration.

\subsubsection{Effect of UV irradiation on voltammetric behaviour of BDD electrode [35]}

Figure 3 shows the cyclic voltammograms of BDD electrode in the absence and in the presence of 4-aminophenol without and under UV irradiation. In the absence of 4-AP no difference between the cyclic voltammograms was noticed, thus UV irradiation does not influence the BDD electrode behaviour. In the presence of 4-AP without UV irradiation, the potential where the direct electrochemical oxidation of 4-AP is established. Under UV irradiation, the photoresponse of anodic current is higher and more two oxidation peaks at about $+0.5 \mathrm{~V}$ and $+0.9 \mathrm{~V}$ vs. $\mathrm{Ag} / \mathrm{AgCl}$ appear. This aspect could be attributed to changing the mechanism of the electrochemical oxidation of 4-AP, involving the further oxidation occurring, which was similar with the above-mentioned results found at the high potential scan rate. Also, the higher current under UV irradiation could be attributed to increase in the degradation rate of 4 -AP.

Based on the above-presented results and taking into account the open circuit potential behavior evolution of BDD electrode under UV irradiation and the presence of $\mathrm{TiO}_{2}$ supported catalyst [35], it may be postulated that the 4-AP oxidation exhibited a complex mechanism. 4-AP could be oxidised directly on the anode and indirectly by hydrogen 
peroxide and hydroxyl radicals. When $\mathrm{Z}-\mathrm{TiO}_{2}$ particles are illuminated at a wavelength shorter than $400 \mathrm{~nm}$, the generation of electron-hole pairs takes place. The photoelectrons act as reducing agents and peroxide radical $\left(\mathrm{O}_{2}^{\bullet-}\right)$ is generated, which may become a source of other oxidising species, such as hydrogen peroxide and hydroxyl radicals. The photogenerated holes have a high positive oxidation potential to oxidise organic compounds and water to form hydroxyl radicals $\left(\mathrm{HO}^{\circ}\right)$, which are the main oxidising species in the photocatalysis. In an electric field, the major electrochemical reactions occur as follows: anode-direct oxidation, under water stability potential region, equation (6), under water decomposition potential region equation (7), cathode-under water decomposition potential region, equation (8).

$$
\begin{gathered}
4-\mathrm{AP}-n e^{-} \rightarrow \text { Products } \\
2 \mathrm{H}_{2} \mathrm{O}-2 e^{-} \rightarrow 2 \mathrm{OH}^{\bullet}+2 \mathrm{H}^{+} \\
\mathrm{O}_{2}+2 \mathrm{H}_{2} \mathrm{O}+4 e^{-} \rightarrow 2 \mathrm{H}_{2} \mathrm{O}_{2}
\end{gathered}
$$
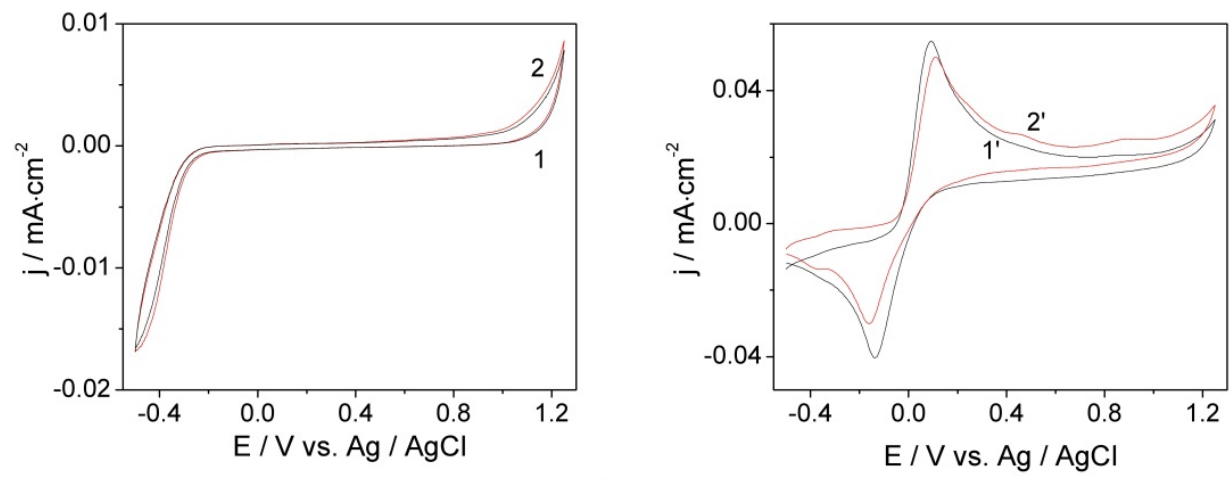

a)

b)

Figure 3. Cyclic voltammograms recorded at BDD electrode in: (a) $1 \mathrm{M} \mathrm{Na} 2 \mathrm{SO}_{4}$ supporting electrolyte under dark (1) and UV irradiation (2); and (b) in the presence of $50 \mathrm{mgL}^{-1} 4-\mathrm{AP}$ under dark (1') and UV irradiation (2') at the potential scan rate of $0.1 \mathrm{Vs}^{-1}$.

\subsubsection{Chronoamperometric and multiple-pulsed amperometry results}

To establish the best operating conditions, chronoamperometry measurements were performed to determine the electrode performance for electrochemical and photocatalytically-assisted electrochemical degradation of organics. The chronoamperograms recorded for each electrode in the presence of $25 \mathrm{mgL}^{-1} 4-\mathrm{CP}$ during $2 \mathrm{~h}$ of electrolysis are presented in Figure 4. 


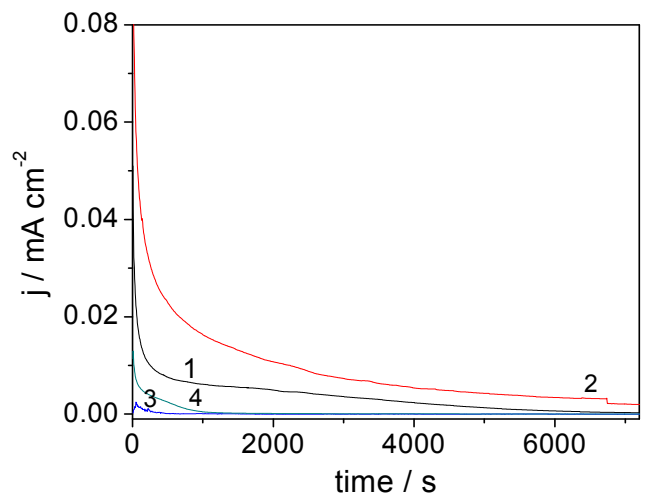

Figure 4. Chronoamperograms recorded at $+1.1 \mathrm{~V}$ vs. Ag/AgCl for: 1-EG-Epoxy, 2-CNF-EG-Epoxy, 3EG-PS, 4-BDD in the presence of $25 \mathrm{mgL}^{-1} 4-\mathrm{CP}$, with the background substracted.

Chronoamperometric results have been used to determine the serie of electroactivities for 4$\mathrm{CP}$ oxidation at the tested electrodes. For a more electroactive material having a diffusion coefficient $\mathrm{D}$, the current corresponding to electrochemical reaction is described by the Cottrell equation [48]:

$$
I(t)=n F A C^{*}(D / \pi)^{1 / 2}
$$

where D and $C^{*}$ represent the diffusion coefficient $\left(\mathrm{cm}^{2 \cdot} \cdot \mathrm{s}^{-1}\right)$, and the concentration of the solution $\left(\mathrm{mol}^{-} \mathrm{cm}^{-3}\right)$, respectively. The dependency between $\mathrm{I}$ and $\mathrm{t}^{-1 / 2}$ is linear, and the diffusion coefficient can be determined from the slope. Accoding to Cottrell equation, the slope is given by the following term: $n F A C^{*}(D / \pi)^{1 / 2}$, and the apparent diffusion constant can be calculated (see Table 3):

\begin{tabular}{|l|c|}
\hline \multirow{2}{*}{ Electrode } & $\begin{array}{c}\text { Apparent diffusion constant, } \\
\mathrm{D}^{\prime}\left(\mathrm{s}^{-1}\right)\end{array}$ \\
\hline EG-Epoxy & $21.20 \cdot 10^{-6}$ \\
CNF-EG-Epoxy & $58.97 \cdot 10^{-6}$ \\
PS-EG & $4.269 \cdot 10^{-9}$ \\
BDD & $1.378 \cdot 10^{-6}$ \\
GC & $194.6110^{-6}$ \\
\hline
\end{tabular}

Table 3. Apparent diffusion constant of 4-CP

From the above presented results, the electroactivity serie for 4-CP oxidation at the tested

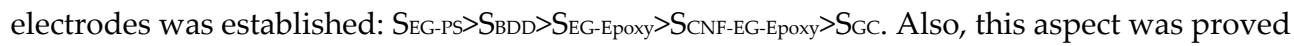
by process efficiency and electrochemical efficiency determination based on the 4-CP concentration monitoring using UV-VIS spectrophotometry measurements (see Table 4). 


\begin{tabular}{|l|c|c|}
\hline Electrode & $\begin{array}{c}\text { Process efficiency } \\
(\eta \mathrm{CF}) \\
(\%)\end{array}$ & $\begin{array}{c}\text { Electrochemical } \\
\text { efficiency }(\mathrm{EcF}) \\
\left(\mathrm{g} \cdot \mathrm{C}^{-1} \cdot \mathrm{cm}^{-2}\right)\end{array}$ \\
\hline EG-Epoxy & 17.26 & $4.74 \cdot 10^{-4}$ \\
CNF-EG-Epoxy & 20.14 & $2.73 \cdot 10^{-4}$ \\
EG-PS & 23.09 & $3.20 \cdot 10^{-2}$ \\
GC & 4.47 & $0.12 \cdot 10^{-4}$ \\
BDD & 9.14 & 6.73 \\
\hline
\end{tabular}

Table 4. Process efficiency ( $\eta_{\mathrm{C} F}$ ) and electrochemical efficiency $\left(\mathrm{E}_{\mathrm{CF}}\right)$ for 4-CP degradation by chronoamperometry

In general, the dependence of the electrochemical reaction rates on the concentration of organic pollutants has been described by a pseudo first-order equation based on the relation $\ln \left(\mathrm{C}_{0} / \mathrm{C}_{\mathrm{t}}\right)=\mathrm{kapp}_{\mathrm{a}}(\mathrm{t})$. Also, the apparent rate constant was calculated based on the relation of $\ln \left(\mathrm{C}_{0} / \mathrm{C}_{\mathrm{t}}\right)=\mathrm{k}^{\prime}{ }_{\text {app }}(\mathrm{C})$, in which $\mathrm{C}$ represents the electrical charge passed during electrochemical oxidation of $4-\mathrm{CP}$. The kinetic results were obtained by monitoring changes in 4-CP concentration as a function of the reaction time. Based on the results gathered in Table 4 can be concluded that 4-CP oxidation process occurred with a fast kinetics on carbon composite electrode. However, in terms of charge consumption, the BDD electrode exhibited the best apparent rate constant, an expected result takes into account that no oxygen evolution occurred at the potential value applied on this electrode and lower electrical charge was involved.

\begin{tabular}{|c|c|c|}
\hline \multirow{2}{*}{ Electrode } & \multicolumn{2}{|c|}{ Rate constant, $\mathrm{k}$} \\
\cline { 2 - 3 } & $\mathrm{K}_{\text {app }}^{\prime} \mathrm{C}^{-1}$ & $\mathrm{~K}_{\text {app }}, \mathrm{s}^{-1}$ \\
\hline EG-Epoxy & 2.041 & $2.638 \cdot 10^{-5}$ \\
CNF-EG-Epoxy & 1.2056 & $3.125 \cdot 10^{-5}$ \\
PS-EG & 1139.47 & $3.646 \cdot 10^{-5}$ \\
GC & 0.0538 & $6.39 \cdot 10^{-6}$ \\
BDD & 1415.3 & $1.33 \cdot 10^{-5}$ \\
\hline
\end{tabular}

Table 5. Electrochemical reaction rate constant of 4-CP at the carbon-based electrodes

Even if the carbon composite electrode exhibited better performances expressed in terms of the process efficiency, BDD electrode exhibited superiority and a real potential for electrochemical degradation based on its electrochemical efficiency in relation with lower energy consumption. An example of optimization of operating conditions using chronoamperometry (CA) for the electrochemical oxidation of 4-aminophenol (4-AP) using boron-doped diamond (BDD) electrode is presented in Figure 5. Various oxidizing potential levels, i.e., $0.5,0.9,1.25$ and $1.75 \mathrm{~V}$ vs. $\mathrm{Ag} / \mathrm{AgCl}$ were applied for optimization. It can be noticed that higher oxidation potential value better degradation process efficiency but with higher energy consumption that decrease the electrochemical efficiency and limits for the practical applications. 

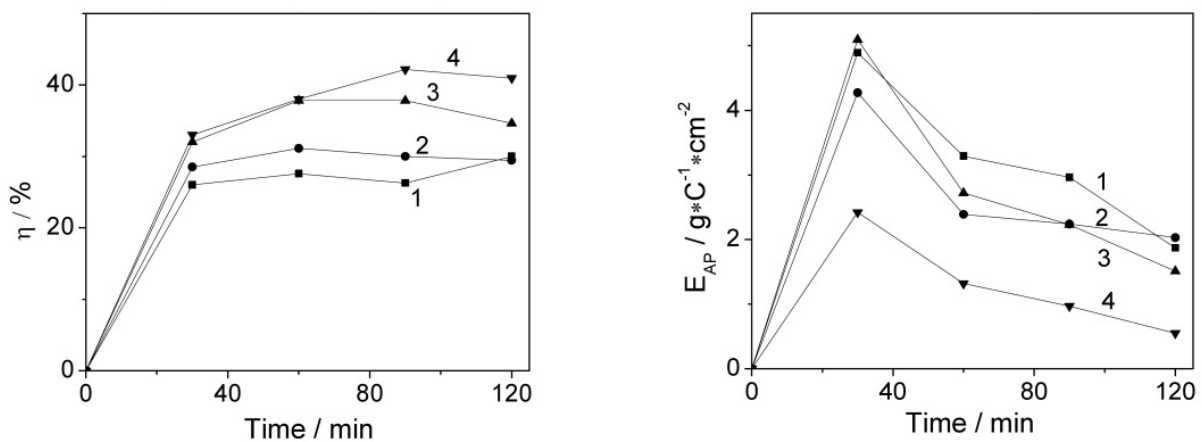

a)

b)

Figure 5. 4-AP removal efficiency (a) and electrochemical efficiency (b) by electrooxidation process using BDD electrode in $1 \mathrm{M} \mathrm{Na}_{2} \mathrm{SO}_{4}$ and in the $64 \mathrm{mg} \cdot \mathrm{L}^{-1} 4-\mathrm{AP}$; the applied techniques are: curve 1 $\mathrm{E}=0.5 \mathrm{~V}$ vs $\mathrm{Ag} / \mathrm{AgCl}$, curve $2-\mathrm{E}=0.9 \mathrm{~V}$ vs $\mathrm{Ag} / \mathrm{AgCl}$, curve $3-\mathrm{E}=1.25 \mathrm{~V}$ vs $\mathrm{Ag} / \mathrm{AgCl}$, curve $4-\mathrm{E}=1.75 \mathrm{~V}$ vs $\mathrm{Ag} / \mathrm{AgCl}$.

Multiple-pulsed amperometry (MPA) is a technique appropriate for in-situ electrochemical cleaning of an electrode during the oxidation process. The effect of MPA applying is presented here in comparison with optimized CA technique for the electrochemical oxidation of 4-AP using boron-doped diamond (BDD) electrode. The operating conditions for MPA, a cleaning potential of $+1.75 \mathrm{~V}$ and an oxidation potential value of $+1.25 \mathrm{~V}$ vs. $\mathrm{Ag} / \mathrm{AgCl}$ were selected, taking into account that the oxidation potential is similar to that of $\mathrm{CA}$ and that the cleaning potential should be higher but very close the oxygen evolution potential.
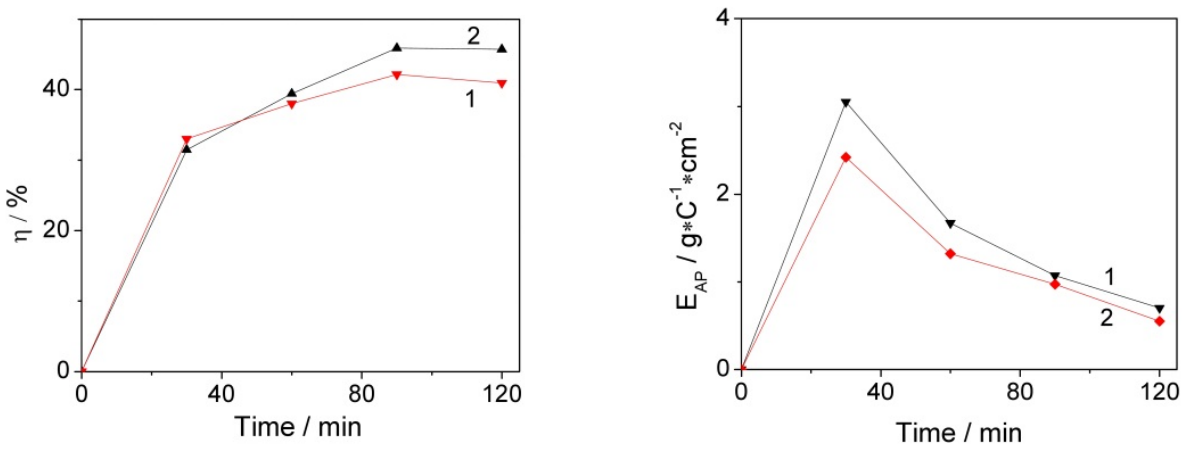

a)

b)

Figure 6. 4-AP removal efficiency (a) and electrochemical efficiency (b) by electrooxidation process using BDD electrode in $1 \mathrm{M} \mathrm{Na}_{2} \mathrm{SO}_{4}$ and in the $64 \mathrm{mg} \cdot \mathrm{L}^{-1} 4$-AP; the applied techniques are: curve $1-\mathrm{CA}$, curve 2 - MPA.

Even if MPA application as an electrochemical process provided better results in terms of the 4-AP degradation process efficiency $(\eta, \%)$ (Figure 6a), better electrochemical activity in 
terms of the electrochemical degradation efficiency was reached in CA application (Figure $6 \mathrm{~b})$. This is a reasonable result because during pulse application of $+1.75 \mathrm{~V}$ a proportion of the current was consumed for oxygen evolution as a side reaction. Applying MPA operating conditions by selecting potential values of +1.25 and $+1.75 \mathrm{~V}$, respective vs. $\mathrm{Ag} / \mathrm{AgCl}$ enables the electrochemical oxidation of 4-AP to take place, through both direct oxidation on the electrode surface and indirect oxidation by electrogeneration of the oxidants under the water decomposition potential.

\subsection{Bulk electrolysis for the electrochemical degradation of 4-aminophenol using boron-doped diamond electrode}

As example of bulk electrochemical degradation is given for 4-AP performed at two current densities, 5 and $10 \mathrm{~mA} \mathrm{~cm}^{-2}$, which were selected in according with the literature data [42] to generate hydroxyl radicals with low energy consumption, and the results are presented in Figures 7 and 8 .

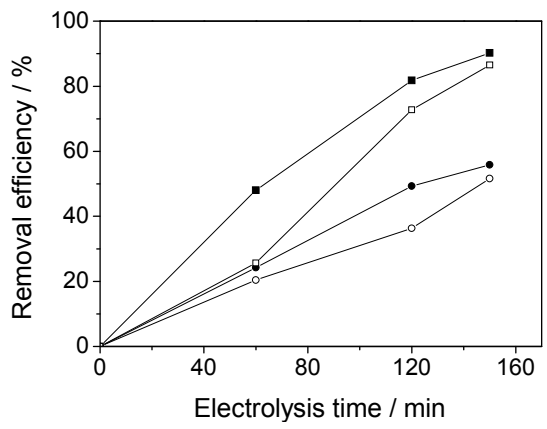

Figure 7. Evolution of removal efficiency of 4-AP determined by spectrophotomertry (solid) and TOC (open) by electrooxidation at the current density of $10 \mathrm{~mA} \mathrm{~cm}^{-2}(\mathbf{\square})$ and $5 \mathrm{~mA} \mathrm{~cm}-2(\bullet)$.

It can be observed that both process efficiencies determined by spectrophotometry and total organic carbon (TOC) parameter increase with electrolysis time and respective, with specific electrical charge passed in the electrochemical oxidation (Figure 7). TOC parameter was checked to assess the mineralization degree. Based on the literature data concerning the phenol based organics electrooxidation under water decomposition potential range, 4-AP electrooxidation occurred in two stages, e.g., the first stage of 4-AP transformation into carboxylic acids and the second stage of the further oxidation of carboxylic acid to carbon dioxide [42]. The difference between 4-AP concentration and TOC evolution with the electrolysis time for both applied current densities proved the existence of the two oxidation stages. Better results were obtained by application of higher current density $\left(10 \mathrm{~mA} \mathrm{~cm}^{-2}\right)$ for the same electrolysis time but it has to take in consideration that for higher current density higher specific electrical charge passed in the electrochemical oxidation, the aspect that limited the application from the economic consideration. The results of the electrochemical performance presented in Figure 8 show that the electrolysis cell operating at the current 
density of $5 \mathrm{~mA} \mathrm{~cm}^{-2}$ lead to the better results for 4-AP degradation and mineralization due to more part of electrical charge is consumed for the abundant oxygen evolution at higher current density applying. Also, an electrolysis time of 60 minutes should be considered as optimum.

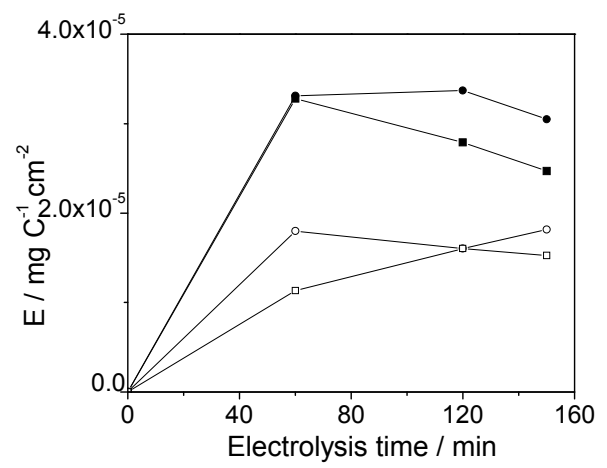

Figure 8. Evolution of removal electrochemical efficiency of 4-AP determined by spectrophotometry (solid) and TOC (open) by electrooxidation at the current density of $10 \mathrm{mAcm}^{-2}(\mathbf{m})$ and $5 \mathrm{~mA} \mathrm{~cm}^{-2}(\bullet)$.

During electrolysis, the cell voltage remains constant that informs that no electrode fouling occurred. Also, the $\mathrm{pH}$ of the residual solution first decreased slightly and later increased to reach a value close to 8 . These changes can be attributed to both anodic and cathodic processes which occur in the cell. On the cathode the main reaction is the electrochemical generation of hydroxyl species by hydrogen peroxide reduction at the cathode surface [49], which led to the alkaline $\mathrm{pH}$. At the same time, on the anode several reactions coexist, i.e., organic oxidation and oxygen evolution. The oxygen evolution led a $\mathrm{pH}$ decrease. The organic oxidation with the carboxylic acids formation in the first stage and subsequently its oxidation to carbon dioxide are supported by $\mathrm{pH}$ evolution, thus, the presence of the carboxylic acids lead to a $\mathrm{pH}$ decrease and by its conversion the $\mathrm{pH}$ is increased [36].

In addition, the relationship between mineralization current efficiency, specific energy consumption and electrolysis time for each current density is shown in Figure 9. For the same electrolysis time, at higher current density the charge consumed and implicit, specific energy consumption increased.

The initial $\mathrm{pH}$ is one of the most important operating parameter in the electrooxidation process. The performance of 4-AP degradation and mineralization process by electrooxidation was slightly improved under more alkaline versus acidic conditions. The influence of the $\mathrm{pH}$ mainly acts on the level of the oxidation mechanism under water decomposition region via the action of hydroxyl radicals physisorbed on BDD surface [50]. Alkaline media may favor the generation of hydroxyl radical and the electrooxidation performance is improved. Also, the electroactive species in alkaline medium is more easily oxidized than that of acidic medium (protonated form) [49]. 


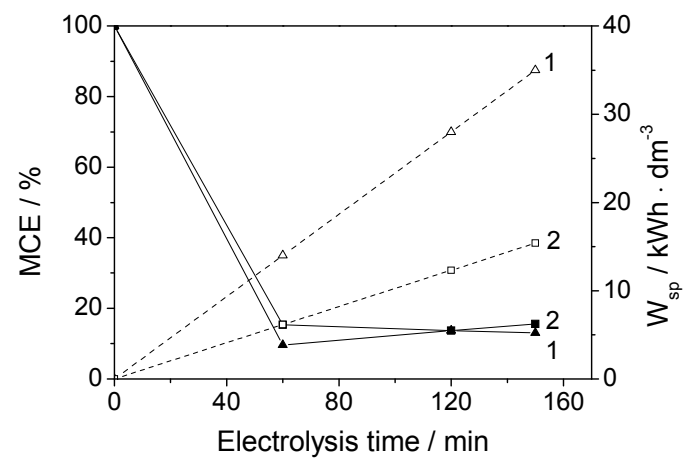

Figure 9. Evolution of the mineralization current efficiency (solid) and the specific energy consumption (open) with the electrolysis time in the electrochemical oxidation of 4-AP in $0.1 \mathrm{M} \mathrm{Na}_{2} \mathrm{SO}_{4}$ supporting electrolyte at the current densities of $10 \mathrm{~mA} \mathrm{~cm}^{-2}$ (curve 1) and $5 \mathrm{~mA} \mathrm{~cm}^{-2}$ (curve 2).

\subsubsection{Photocatalytically-assisted electrochemical oxidation of 4- $A P$ using BDD electrode and TiO2-supported zeolite catalyst}

Based on the above-presented results, a high current density applying is limited by economic criterion. In according with the literature data [51-56] the presence of a catalyst in the electrical field can enhance the treatment efficiency with lower energy consumption. In order to improve the treatment performance of the 4-AP degradation and mineralization at lower current density $\left(5 \mathrm{mAcm}^{-2}\right)$, the application of photocatalysis using $\mathrm{TiO}_{2}$-supported zeolite catalyst on the bulk electrolysis using BDD electrode was performed.

UV spectra of 4-AP evolution presented in Figure 10 were recorded comparatively with initial 4-AP after the application of each oxidation process, i.e., electrooxidation, photocatalytycally -assisted electrooxidation at the same current density in comparison with photocatalysis using $1 \mathrm{~g} \mathrm{dm}^{-3} \mathrm{TiO}_{2}$-supported zeolite catalyst. The photocatalytically-assisted electrooxidation seems to be the most efficient in comparison with the photocatalysis and electrooxidation processes.

The progression of 4-AP degradation by above-presented processes indicated different oxidation efficiencies, and the profiles are presented in Figure 11a. The degradation assessment at 60 minutes showed that the lowest 4-AP degradation efficiency was reached by photocatalysis. Thus, after the reaction time of 120 minutes, about 23,56 and $88 \%$ of 4 AP was degraded in the photocatalysis, electrochemical oxidation and respective, photocatalytically-assisted electrooxidation. Thus, it can be seen that the net efficiency of combined process was greater than the sum of both electrooxidation and photocatalysis processes. This can be regarded as a synergetic effect of the photocatalytically-assisted electrooxidation process.

To assess the 4-AP mineralization by all above-presented processes, the progression of 4-AP degradation expressed in terms of TOC is shown in Figure 11b. After the reaction time of 
120 minutes, about 16, 36 and $72 \%$ of TOC was removed by the application of photocatalysis, electrochemical oxidation and respective, photocatalysis-assisted electrooxidation. The lower values of TOC removal degrees compared with 4-AP removal ones supported the fact that for all applied oxidation processes the complete mineralization of 4-AP to $\mathrm{CO}_{2}$ was occurred via intermediaries as carboxylic acids.

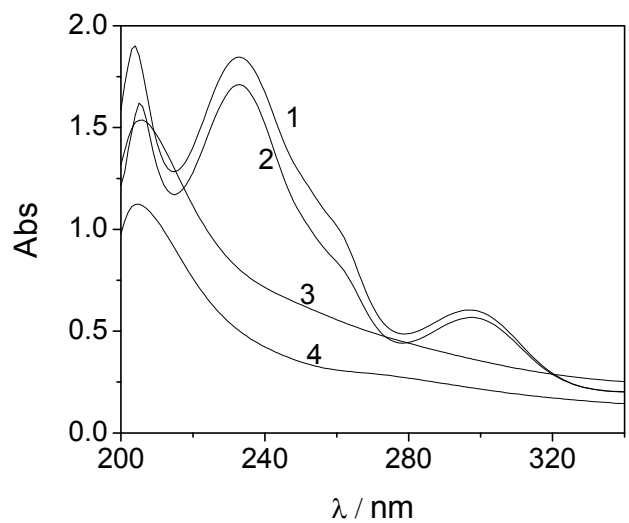

Figure 10. UV spectra profiles of 4-AP after degradation by photocatalysis (2), electrooxidation (3), photocatalytically-assisted electrooxidation (4), in comparison with initial 4-AP (1).

In general, the dependence of electrochemical reaction rates on the concentration of organic pollutants has been described by a pseudo first-order equation. Also, the photocatalysis reaction rate follows the Langmuir-Hinshelwood kinetic model, which can be simplified to a pseudo first-order equation [39]. For all applied oxidation processes the pseudo first-order equation was chosen to determine the apparent rate constant ( $\left.\mathrm{k}_{\mathrm{app}}\right)$, which was calculated based on the relation of $\ln \left(\mathrm{C}_{0} / \mathrm{C}_{\mathrm{t}}\right)=\mathrm{k}_{\mathrm{app}}(\mathrm{t})$. The kinetic results were obtained by monitoring of changes in 4-AP concentration determined by spectrophotometry and TOC parameter as a function of the reaction time. Table 6 shows the apparent rate constant for each applied oxidation process.

The apparent rate constant determined by spectrophotometry analysis of photocatalyticallyassisted electrooxidation was higher by 8.1 and 2.5 times than photocatalysis and electrooxidation, respectively. Also, the apparent rate constants determined by TOC analysis are higher by 9.6 and 2.6 times versus photocatalysis and electrooxidation, respectively. The kinetics of TOC reduction in all applied processes showed that TOC reduction was slower in the photocatalytic process, suggesting that photocatalysis process was inefficient in the mineralization and quite degradation of 4-AP.

According to the definition of the synergetic effect $(\mathrm{SF})=\mathrm{k}_{\mathrm{app}}$, photocatalytically-assisted electrooxidation -

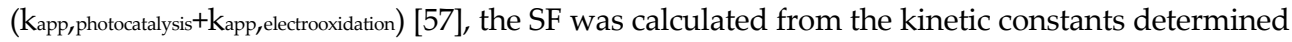
by spectrophotometry and TOC analysis. Thus, (SF) spectrophotometry of $0.0068 \mathrm{~min}^{-1}$ and (SF)Tос of $0.00627 \mathrm{~min}^{-1}$ indicated the apparent kinetic synergetic effects in the photocatalytically-assisted electrooxidation process for both degradation and mineralization of 4-AP. 


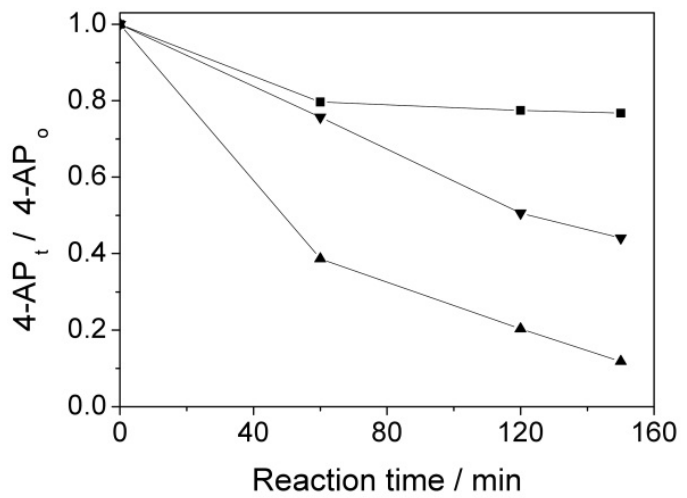

a)

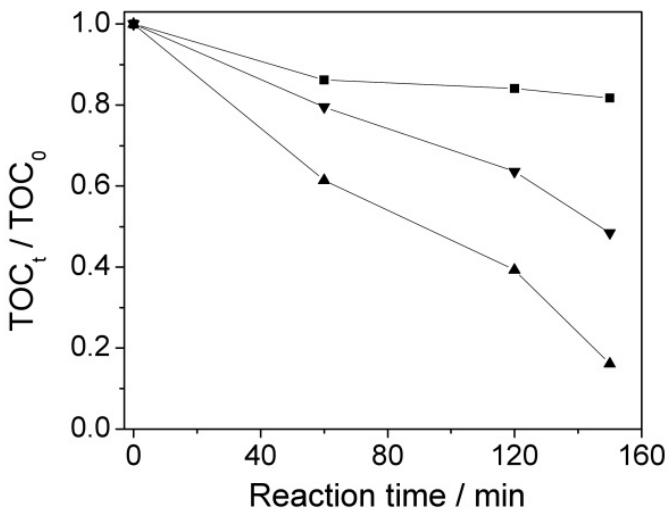

b)

Figure 11. Evolution of 4-AP degradation with the reaction time, expressed as: a) 4-APt/a-APo and b) $\mathrm{TOC}_{\mathrm{t}} / \mathrm{TOC}_{0}$; $(\boldsymbol{\nabla})$ photocatalysis; ( $\left.\mathbf{\nabla}\right)$ electrooxidation; $(\boldsymbol{\Delta})$ photocatalytically-assisted electrooxidation.

\begin{tabular}{|l|l|l|l|}
\hline $\begin{array}{l}\text { Type of 4-AP } \\
\text { determination }\end{array}$ & Applied oxidation process & $\begin{array}{l}\text { Apparent rate } \\
\text { constant, kapp } \\
\left(\mathrm{x} 10^{-3} \mathrm{~min}^{-1}\right)\end{array}$ & $\begin{array}{l}\text { Correlation } \\
\text { factor, } \mathrm{R}^{2}\end{array}$ \\
\hline spectrophotometric & $\begin{array}{l}\text { photocatalysis } \\
\text { electrooxidation } \\
\text { photocatalytically-assisted } \\
\text { electrooxidation }\end{array}$ & $\begin{array}{l}5.68 \\
13.6\end{array}$ & 0.9118 \\
& $\begin{array}{l}\text { photocatalysis } \\
\text { electrooxidation } \\
\text { photocatalytically-assisted } \\
\text { electrooxidation }\end{array}$ & 1.26 & 0.9968 \\
\hline
\end{tabular}

Table 6. The pseudo-first order kinetic apparent constant for the degradation of 4-AP determined by spectrophotometry and TOC analysis 
For the electrochemical and combined processes, the apparent rate constant determined by spectrophotometry and TOC analysis was calculated based on the relation of $\ln \left(\mathrm{C}_{0} / \mathrm{C}_{\mathrm{t}}\right)=\mathrm{k}_{\text {app }}^{\prime}(\mathrm{C})$, in which $\mathrm{C}$ represents the electrical charge passed during electrochemical and combined oxidation of 4-AP. The results are gathered in Table 7, and it can be noticed that the apparent rate constants determined for 4-AP concentration and TOC measurements for photocatalysis-assisted electrooxidation process are the best. Also, the effective mineralization rate was assessed as the ratio between the apparent rate constant calculated for TOC analysis and the apparent rate constant calculated for spectrophotometry analysis

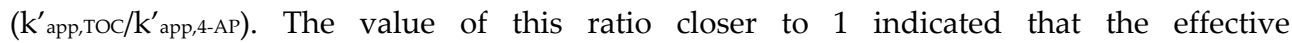
mineralization rate was achieved. The value of 0.88 compared with 0.82 for electrooxidation confirmed the enhancement effect of photocatalysis application on the electrooxidation process of 4-AP using BDD electrode to reach the mineralization.

\begin{tabular}{|l|l|l|l|}
\hline $\begin{array}{l}\text { Type of 4-AP } \\
\text { determination }\end{array}$ & Applied oxidation process & $\begin{array}{l}\text { Apparent rate } \\
\text { constant, } \mathrm{k}_{\text {app }}\left(\mathrm{C}^{-1}\right)\end{array}$ & $\begin{array}{l}\text { Correlation } \\
\text { factor, } \mathrm{R}^{2}\end{array}$ \\
\hline spectrophotometric & $\begin{array}{l}\text { electrooxidation } \\
\text { photocatalytically-assisted } \\
\text { electrooxidation }\end{array}$ & $\begin{array}{l}0.240 \\
0.586\end{array}$ & $\begin{array}{l}0.9968 \\
0.9961\end{array}$ \\
\hline TOC & $\begin{array}{l}\text { electrooxidation } \\
\text { photocatalytically-assisted } \\
\text { electrooxidation }\end{array}$ & 0.196 & 0.9633 \\
\end{tabular}

Table 7. The apparent rate constant for the degradation of 4-AP determined by spectrophotometry and TOC analysis function of electrical charge

The enhancement effect of the combination of photocatalysis and electrooxidation processes operating at high voltage or current density may be attributed to two major factors, i.e., reducing the recombination of hole-electron pair resulted from photocatalysis, and indirect electrochemical oxidation of 4-AP. In according with literature data [57] it is supposed that the degradation mechanism is very complex, involving many oxidation pathways, e.g., anodic oxidation involving oxygen evolution, oxidation by electrogenerated $\mathrm{H}_{2} \mathrm{O}_{2}$ and $\mathrm{OH} \bullet$, oxidation by photogenerated hole and $\mathrm{OH} \bullet$ and the photoelectrocatalytic synergetic effect.

It is well-known that the operating cost of an electrochemical oxidation depends strongly on the cell voltage as the specific energy consumption ( $\left.\mathrm{W}_{\mathrm{sp}}\right)$. By the application of photocatalysis-assisted electrooxidation process for 4-AP degradation a higher mineralization current efficiency at low specific energy consumption was reached (Figure 12). It was found that for the same energy consumption of $12 \mathrm{kWhm}^{-3}$, photocatalysisassisted electrooxidation process allowed removing $72 \%$ TOC in comparison with the electrochemical process for which $32 \%$ TOC removal was achieved. Thus, both technical and economic aspects regarding degradation process of 4-AP from water suggested the superiority of photocatalytically-assisted electrooxidation process in comparison with the electrochemical process [36]. 


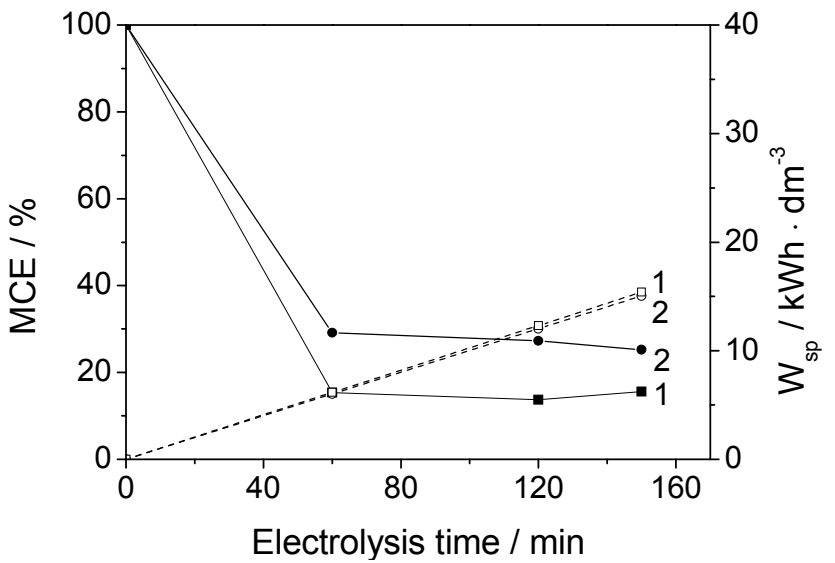

Figure 12. Evolution of the mineralization current efficiency (solid) and the specific energy consumption (open) with the electrolysis time in the electrochemical oxidation of 4-AP in $0.1 \mathrm{M} \mathrm{Na}_{2} \mathrm{SO}_{4}$ electrolyte for the application of: 1-electrooxidation; 2- photocatalytically-assisted electrooxidation.

It is clear that the (photo)electrochemical processes are energy consumption, being more expensive in comparison with the conventional biological process, but it must be taken into consideration that the (photo)electrochemical processes are considered advanced treatment one and should be integrated within the conventional treatment technological flow. When the electrochemical oxidation is the stage prior to biological one, biodegradability of the organic pollutants is enhanced, improving the performance of the biological process. In contrast, application of electrochemical oxidation as a finishing step envisaging completely mineralizing the refractory organic matter after biological treatment. A reduction of $25 \%$ of the energy consumption was reported by Panizza after coupling the electrooxidation and the biological processes [58].

\subsection{Dual role of the electrochemical methods for organics degradation and determination}

It is noteworthy that electrode materials for water quality monitoring by voltammetric/amperometric detection are conceptually very similar to those used in the degradation of pollutants from water, so the development of suitable electrode materials and electrochemical techniques involves actually relatively easy adaptation from a field to another, taking into account the application peculiarities, e.g., electrode geometry and design for degradation application. As example, the assessment of 4-CP concentration after chronoamperometry applying using EG-Epoxy composite electrode at the potential value of $+1.1 \mathrm{~V}$ vs. $\mathrm{Ag} / \mathrm{AgCl}$ after two hours of electrolysis was performed by using the cyclic voltammetric detection with the same electrode in comparison with spectrophotometric and classical chemical oxygen demand (COD) method. Figure 13 shows CVs recorded for initial $4-\mathrm{CP}$ concentration and after chronoamperometry applying. The reduction degrees of $4-\mathrm{CP}$ 
concentration by applying the chronoamperometry, determined by cyclic voltammetric detection, spectrophotometric and classical COD method are shown in Table 8.

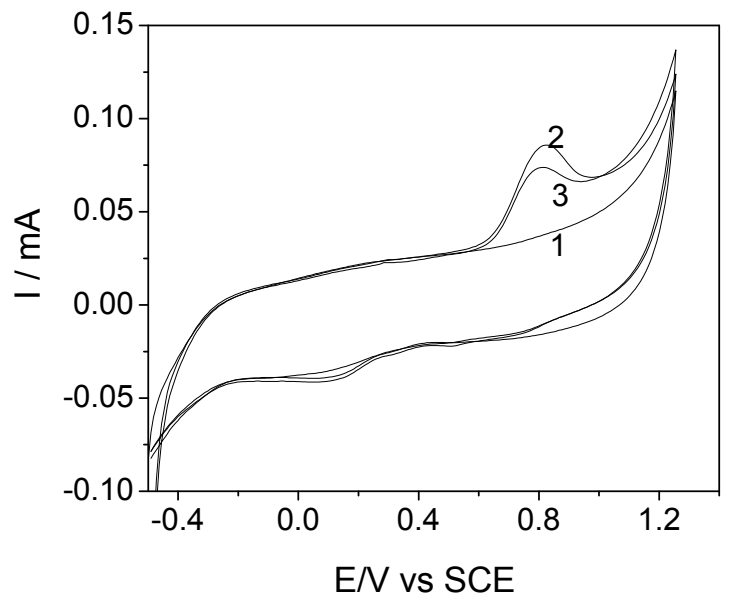

Figure 13. Cyclic voltammograms of EG-Epoxy in $0.5 \mathrm{M} \mathrm{Na}_{2} \mathrm{SO}_{4}$ supporting electrolyte (1) and in the presence of $25 \mathrm{mgL}^{-1} 4-\mathrm{CP}$ concentrations: before (2) and after (3) chronoamperometry applying at +1.1 $\mathrm{V}$ vs. $\mathrm{Ag} / \mathrm{AgCl}$ for $2 \mathrm{~h}$.

\begin{tabular}{|l|l|l|}
\hline $\begin{array}{l}\text { 4-CP reduction degree } \\
(\%)\end{array}$ & $\begin{array}{l}\text { COD reduction degree } \\
(\%)\end{array}$ & $\begin{array}{l}\text { Amperometric signal reduction } \\
\text { degree }(\%)\end{array}$ \\
\hline 17.26 & 15 & 18 \\
\hline
\end{tabular}

Table 8. The reduction degree of 4-CP concentration by applying the chronoamperometry at the potential value of $+1.1 \mathrm{~V}$ vs. $\mathrm{Ag} / \mathrm{AgCl}$ for two hours

Compared with the initial concentration of 4-CP, cyclic voltammogram shape recorded after chronoamperometry applying is changed, the current at the higher potential value but below oxygen evolution increased. This aspect could be explained by the intermediate formation of 4-CP oxidation which is oxidizable at higher potential value, e.g., carboxilic acid that is oxidized on composite electrode at the potential value of $1.1 \mathrm{~V}$ vs. SCE [59]. This behaviour is in concordance with spectrophotometric and COD results, denoting a good accuracy of the voltammteric method and suitability for degradation process control.

\section{Conclusions}

Electrochemical processes should be regarded as viable alternatives for enhanced conventional wastewater treatment technology. Based on the wastewater characteristics and further usage, the various electrochemical processes could be applied individually or/and integrated into a variety of technological flows involving physical, chemical and biological methods. The electrocoagulation process could replace the conventional coagulation method integrated into a technological flow containing or not the electrooxidation process as 
advanced water treatment method. Also, the electrooxidation process could be applied as advanced oxidation process suitable especial for degradation/mineralization of the recalcitrant organic pollutants from wastewaters. The efficiency of electrochemical oxidation system is given mainly by the electrode material, which represents the key of the process performance. Carbon-based electrodes represent very promising electrode materials for degradation and mineralization of phenol derivates from wastewaters. Pulsed voltage application allows in-situ electrochemical cleaning the electrode materials leading to enhanced electrode performance, but its common usage is limited by higher energy consumption. Very promising results in relation with technical-economic criteria were achieved using photocatallytically-assissted electrooxidation process for degradation and mineralization of organics from wastewaters in comparison with simple electrooxidation process. Moreover, it must be kept in mind that the economic aspects will be improved by integration of the (photo)electrochemical process within the conventional treatment technological flow before or after the biological stage in accordance with the practical requirements, to improve the biodegradability of the recalcitrant organics or to mineralize them. Another important aspect that is not exploited is represented by dual role of the electrode material and electrochemical method in wastewater treatment and quality control, which could allow to set-up the electrochemical process control-integrated wastewater electrochemical treatment flow. A major area for future research is to establish the methodologies for the integration of the electrochemical treatment process involving more cost-effective electrodes in wastewaters decontamination and quality control.

\section{Author details}

Florica Manea* and Aniela Pop

Faculty of Industrial Chemistry and Environmental Engineering

"Politehnica" University of Timisoara, Romania

\section{Acknowledgement}

This work was partially supported by the strategic grants POSDRU/89/1.5/S/57649, Project ID 57649 (PERFORM-ERA), POSDRU/21/1.5/G/13798 co-financed by the European Social Fund - Investing in People, within the Sectoral Operational Programme Human Resources Development 2007-2013 and partially by the PN-II-ID-PCE 165/2011 and PNII-RUPD129/2010 Grants.

\section{References}

[1] Metcalf \& Eddy Inc. (1991) Wastewater Engineering: Treatment, Disposal and Reuse. New York: McGraw-Hill. 1334 p.

\footnotetext{
${ }^{*}$ Corresponding Author
} 
[2] Kim KH, Ihm SK (2011) Heterogeneous Catalytic Wet Air Oxidation of Refractory Organic Pollutants in Industrial Wastewaters: A Review. J. hazard. mat. 186(1): 1634.

[3] Liotta LF, Gruttadauria M, Di Carlo G, Perrini G, Librando V (2009) Heterogeneous Catalytic Degradation of Phenolic Substrates: Catalysts Activity. J. hazard. mat. 162( 23): 588-606.

[4] Busca G, Berardinelli S, Resini C, Arrighi L (2008) Technologies for The Removal of Phenol from Fuid Streams: A Short Review of Recent Developments. J. hazard. mat. 160: 265-288.

[5] Bapat PS, Gogate PR, Pandit AB (2008) Theoretical Analysis of Sonochemical Degradation of Phenol and Its Chloro-Derivatives. Ultrason. sonochem. 15( 4): 564570 .

[6] Barrios-Martinez A, Barbot E, Marrot B, Moulin P, Roche N (2006) Degradation of Synthetic Phenol-Containing Wastewaters by MBR. J. membr. sci. 281(1-2): 288296.

[7] ${ }^{* * *}$ Directive 2008/1/EC of the European Parliament and of the Council of 15 January 2008 concerning integrated pollution prevention and control.

[8] Rajeshwar K, Ibanez JG (1997) Environmental Electrochemistry. San Diego: Academic Press. 776 p.

[9] Rajeshwar K, Ibanez JG, Swain GM, (1994) Electrochemistry and Environment. J. appl. electrochem. 24: 1077-1091.

[10] Walsh FC (2001) Electrochemical Technology for Environmental Treatment and Energy Conversion. Pure appl. chem. 73: 1819-1837.

[11] Chen G (2004) Electrochemical Technologies in Wastewater Treatment. Sep. puri. technol. 38: 11-41.

[12] Bebeselea A, Pop A, Orha C, Danielescu C, Manea F, Burtica G (2006) Aspects Regarding The Wastewater Treatment by Electroflotocoagulation. Environ. eng. manag. j. 5(5): 1071-1077.

[13] Mouli PC, Mohan SV, Reddy SJ (2004) Electrochemical Processes for The Remediation of Wastewater and Contaminated Soil: Emerging Technology, J. sci. ind. res. 63: 11-19.

[14] Ciorba GA, Radovan C, Vlaicu I, Masu S (2002) Removal of Nonylphenol Ethoxylates by Electrochemically-Generated Coagulants. J. appl. electrochem. 32: 561-566.

[15] Jiang JQ, Graham N, Andre C, Kelsall GH, Brandon N (2002) Laboratory Study of Electro-Coagulation-Flotation for Water Treatment. Wat. res. 36: 4064-4078.

[16] Chen X, Chen G, Yue PL (2000) Separation of Pollutants From Restaurant Wastewater by Electrocoagulation, Sep. purif. technol. 19:65-76.

[17] Pouet MF, Grasmick A (1995) Urban Wastewater Treatment Electrocoagulation and Flotation. Water sci. technol. 31: 275-283. 
[18] Anglada A, Urtiaga A, Ortiz I (2009) Contributions of Electrochemical Oxidation to Waste-Water Treatment: Fundamentals and Review of Applications. J. chem. technol. biotechnol. 84: 1747-1755.

[19] Comninellis Ch (1994) Electrocatalysis in The Electrochemical Conversion/Combustion of Organic Pollutants for Waste Water Treatment. Electrochim. acta. 39(11-12): 18571862.

[20] Brillas E, Arias C, Cabot PL, Centellas F, Garrido JA, Rodriguez RM (2006) Degradation of Organic Contaminants by Advanced Electrochemical Oxidation Methods. Port. Electrochim. Acta. 24: 159-189.

[21] Yoshida K, Yoshida S, Seki Y, Takahashi T, Ihara I, Toyoda K (2007) Basic Study Of Electrochemical Treatment of Ammonium Nitrogen Containing Wastewater Using Boron-Doped Diamond Anode. Environ. res. 65: 71-73.

[22] Motoc S, Manea F, Pop A, Pode R, Teodosiu C (2012) Electrochemical Degradation of Pharmaceutical Effluent on Carbon-Based Electrodes. Environ. eng. manag. j. 11(3): 627634.

[23] Hegde RN, Shetti NP, Nandibewoor ST (2009) Electro-Oxidation and Determination of Trazodone at Multi-Walled Carbon Nanotube-Modified Glassy Carbon Electrode. Talanta. 79: 361-368.

[24] Patil RH, Hegde RN, Nandibewoor ST (2011) Electro-Oxidation and Determination of Antihistamine Drug, Cetirizinen Dihydrochloride at Glassy Carbon Electrode Modified with Multi-Walled Carbon Nanotubes. Coll. surf. B: biointerf. 83: 133-138.

[25] Shahrokhian S, Souri A, Khajehsharifi H (2004) Electrocatalytic Oxidation of Penicillamine at a Carbon Paste Electrode Modified with Cobalt Salophen. J. electroanal. chem. 565: 95-101.

[26] Brillas E, Garcia-Segura S, Skoumal M, Arias C (2010) Electrochemical Incineration of Diclofenac in Neutral Aqueous Medium by Anodic Oxidation using Pt and BoronDoped Diamond Anodes. Chemosphere. 79: 605-612.

[27] Dominguez JR, Gonzalez T, Palo P, Sanchez-Martin J (2010) Anodic Oxidation of Ketoprofen on Boron-Doped Diamond (BDD) Electrodes. Role of Operative Parameters. Chem. eng. j. 162: 1012-1018.

[28] Garrido JA, Brillas E, Cabot PL, Centellas F, Arias C, Rodriguez RM (2007) Mineralization of Drugs in Aqueous Medium by Advanced Oxidation, Port. electrochim. Acta. 25: 19-41.

[29] Klavarioti M, Mantzavinos D, Kassinos D (2009) Removal of Residual Pharmaceuticals from Aqueous Systems by Advanced Oxidation Processes, Environ. int. 35: 402-417.

[30] Manea F, Radovan C, Pop A, Corb I, Burtica G, Malchev P, Picken S, Schoonman J (2009) Carbon Composite Electrodes Applied for Electrochemical Sensors. In: Baraton MI editor. Sensors for Environment, Health and Security. NATO Science for Peace and Security Series C: Environmental Security. Springer. pp. 179-189. 
[31] Pop A, Manea F, Radovan C, Malchev P, Bebeselea A, Proca C, Burtica G, Picken S, Schoonman J (2008) Amperometric Detection of 4-Chlorophenol on Two Types of Expanded Graphite based Composite Electrodes. Electroanal. 20(22): 2460-2466.

[32] Orha C, Manea F, Pop A, Burtica G, Fazakas-Todea I (2008) Obtaining and Characterization of Zeolitic Materials with Antibacterial Properties, Rev. chim. 59(2): 173-177.

[33] Corb I, Manea F, Radovan C, Pop A, Burtica G, Malchev P, Picken S, Schoonman J (2007) Carbon-based Composite Electrodes: Preparation, Characterization and Application in Electroanalysis. Sensors. 7: 2626-2635.

[34] Mironov VS, Kim JK, Park M, Lim S, Cho WK (2007) Comparison of Electrical Conductivity Data Obtained by Four-Electrode and Four-Point Probe Methods for Graphite-based Polymer Composites. Polym. test. 26(4): 547-555.

[35] Ratiu C, Manea F, Lazau C, Orha C, Burtica G, Grozescu I, Schoonman J (2011) ZeoliteSupported $\mathrm{TiO}_{2}$ based Photocatalysis-Assisted Electrochemical Degradation of pAminophenol from Water. Chem. pap. 65( 3): 289-298.

[36] Ratiu C, Manea F, Lazau C, Grozescu I, Radovan C, Schoonman J (2010) Electrochemical Oxidation of p-Aminophenol from Water with Boron-Doped Diamond Anodes and Assisted Photocatalytically by $\mathrm{TiO}_{2}$-Supported Zeolite. Desalination. 260: 51-56.

[37] Wang YH, Chan KY, Li XY, So SK (2006) Electrochemical Degradation of 4Chlorophenol at Nickel-Antimony Doped Tin Oxide Electrode. Chemosphere. 65: 10871093.

[38] Vlaicu I, Pop A, Manea F, Radovan C (2011) Degradation of Humic Acid from Water by Advanced Electrochemical Oxidation Method. Wat. sci. technol.: Wat. supp. 11.1: 85-95.

[39] Guinea E, Centellas F, Garrido JA, Rodriguez RM, Arias C, Cabot PL, Brillas E (2009) Solar Photoassisted Anodic Oxidation of Carboxylic Acids in Presence of $\mathrm{Fe}^{3+}$ using a Boron-Doped Diamond Electrode. Appl. catal. B: environ. 89: 459-468.

[40] Wang XG, Wu QS, Liu WZ, Ding YP (2006) Simultaneous Determination of Dinitrophenol Isomers with Electrochemical Method Enhanced by Surfactant and Their Mechanisms Research. Electrochim. acta. 52: 589-594.

[41] Canizares P, Saez C, Lobato J, Rodrigo MA (2004) Electrochemical Treatment of 4Nitrophenol-Containing Aqueous Wastes using Boron-Doped Diamond Anodes. Ind. eng. chem. res. 43, 1944-1951.

[42] Canizares P, Lobato J, Paz R, Rodrigo MA, Saez C (2005) Electrochemical Oxidation of Phenolic Wastes with Boron-Doped Diamond Anodes. Water res. 39: 2687-2703.

[43] Gherardini L, Michaud PA, Panizza M, Comninellis Ch, Vatistas N (2001) Electrochemical Oxidation of 4-Chlorophenol for Waste Water Treatment. Definition of Normalized Current Efficiency. J. electrochem. soc. 148: D78-D84. 
[44] Ureta-Zanartu MS, Bustos P, Berrios C, Diez MC, Mora ML, Gutierrez C (2002) Electrooxidation of 2,4-Dichlorophenol and other Polychlorinated Phenols at a Glassy Carbon Electrode. Electrochim. acta. 47: 2399-2406.

[45] Skowronski JM, Krawczyk P (2007) Improved Electrooxidation of Phenol at Exfoliated Graphite Electrodes. J. solid state electrochem. 11: 223-230.

[46] Manea F, Burtică G, Bebeşelea A, Pop A, Corb I, Schoonman J (2007) Degaradation of 4-Chlorophenol from Wastewater by Electrooxidation using Graphite based Composite Electrodes. Environmental Science and Technology. Starrett SK, Hong J, Wilcock RJ, Li Q, Carson JH, Arnold S, editors. Houston: American Science Press. vol. 1. p.281.

[47] Rodrigo MA, Michaud PA, Duo I, Panizza M, Cerisola G, Comninellis Ch (2001) Oxidation of 4-Chlorophenol at Boron-Doped Diamond electrodes for Wastewater Treatment. J. electrochem. soc. 148: D60-D64.

[48] Bard AJ, Faulkner LR (1980) Electrochemical Methods, Fundamentals and Applications, New Zork: Wiley.

[49] Martinez-Huitle CA, Brillas E (2009) Decontamination of Wastewater Containing Synthetic Organic Dyes by Electrochemical Methods: A General Review. Appl. catal. B: environ. 87: 105-145.

[50] Lissens G, Pieters J, Verhaege M, Pinoy L, Verstraete W (2003) Electrochemical Degradation of Surfactants by Intermediates of Water Discharge at Carbon-Based Electrodes. Electrochim. acta. 48: 1655-1663.

[51] An T, Li G, Xiong Y, Zhu X, Xing H, Liu G (2001) Photoelectrochemical Degradation of Methylene Blue with $\mathrm{Nano}_{\mathrm{TiO}}$ under High Potential Bias. Mater. phys. mech. 4: 101106.

[52] Chen J, Liu M, Zhang J, Ying X, Jin L (2004) Photocatalytic Degradation of Organic Wastes by Electrochemically Assisted $\mathrm{TiO}_{2}$ Photocatalytic System, J. environ. manag. 70: 43-47.

[53] Lei Y, Shen Z, Chen X, Jia J, Wang W (2006) Preparation and Application of Nano-TiO Catalyst in Dye Electrochemical Treatment. Water. SA. 32(2): 205-210.

[54] Shen ZM, Wu D, Yang J, Yuan T, Wang WH, Jia JP (2006) Methods to Improve Electrochemical Treatment Effect of Dye Wastewater. J. hazard. mater. 131: 90-97.

[55] Wang B, Gu L, Ma H (2007) Electrochemical Oxidation of Pulp and Paper Making Wastewater Assisted by Transition Metal Modified Kaolin. J. hazard. mater. 143: 198205.

[56] Gomathi Devi L, Kottam N, Girish Kumar S, Anantha Raju KS (2009) Mechanismof Charge Transfer in The Transition Metal Ion Doped $\mathrm{TiO}_{2}$ with Bicrystalline Framework of Anatase and Rutile: photocatalytic and photoelectrocatalytic activity. Catal. lett. 131(3-4): 612-617.

[57] An T, Zhang W, Xiao X, Sheng G, Fu J, Zhu X (2004) Photoelectrocatalytic Degradation of Quinoline with a Novel Three-Dimensional Electrode-Packed Bed Photocatalytic Reactor. J. photochem. photobiol. A: chem. 161: 233-242. 
[58] Panizza M, Zolezzi M, Nicolella C (2006) Biological and electrochemical oxidation of naphtalenesulfonates. J chem technol biotechnol 81:225-232.

[59] Manea F, Radovan C, Corb I, Pop A, Burtica G, Malchev P, Picken S, Schoonman J (2008) Simultaneous Determination of 4-Chlorophenol and Oxalic Acid using an Expanded Graphite-Epoxy Composite Electrode. Electroanal. 20(5): 1719-1722. 